\title{
重畫原子間力顕微鏡による $\mathrm{Au}(111)$ 表面の 電気化学的酸化還元過程の in-situ 観察
}

\author{
池宮範人 山田浩司 ${ }^{\dagger}$ 原茂太 \\ 大阪大学工学部材料開発工学科

\begin{abstract}
In-situ Observation of Electrochemical Oxidation and Reduction Processes of Au(111) Surface by Atomic Force Microscopy
\end{abstract}

Norihito Ikemiya, Koji Yamada and Shigeta Hara

Department of Materials Science and Processing, Faculty of Engineering, Osaka University, Suita

\begin{abstract}
Keywords: in-situ atomic force microscopy, surface structure, $A u(111)$ surface, electrochemical oxidation and reduction
\end{abstract}
\section{I．緒}

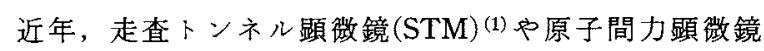
$(\mathrm{AFM})^{(2)}$ を強力な武器として用いて，原子・分子レベルで構 造を制御した材料を創製するナノテクノロジーが展開されつつ ある.このよらな観点から，著者らはAFMによって，多くの 層状化合物の表面および界面構造を原子レベルで明らかにして きた(3)。一般に金属表面は起伏が小さいため，半導体表面の構 造解析にめざましい寄与をしたSTMによっても原子レベルで 観察を行った報告は限られている。最近になって, 電解質溶液 中に就ける $\mathrm{Au}, \mathrm{Pt}$ などの貴金属の表面構造が原子レベルで明 らかルされつつるる(4). STMによる䉓気化学的酸化還元過程 に伴ら Au表面の構造変化については, 板谷ら (5), Trevor ら ${ }^{(6)}$, Vazquez ら (7)によって報告されている.しかしながら, 観察の結果が必ずしも一致して括らず，また酸化物が形成され た場合の詳細なモルフォロジー拈よび原子レベルでの構造につ いては明らかにされていない。また，AFMによっては Manne ら ${ }^{(8)}$ の報告があるのみであり，観察に用いた試料の凹 凸が大きく十分に検討されているとは言い難い。探針に絶縁体 を用いることの可能な AFM では，フォラデー電流の影響を受 けることなく電位制御下の金属表面を安定して観察することが できるという大きな利点を持つ，そこで，本研究では，AFM を用いて $\mathrm{HClO}_{4}$ 溶液中での電気化学的酸化還元過程に伴う $\mathrm{Au}$ 表面の構造変化についてナノスタール拉よび原子レベルで 観察を行った.

\section{II. 実 験}

AFM 観察には真空蒸着法で作製した $\mathrm{Au}(111)$ 配向薄膜を用 いた．基板は大気中でへき開したマイカであり，Au蒸着時の 基板温度は $600 \mathrm{~K}$ とした。まず，ベルジャ一内を $5 \times 10^{-6}$ Torr. 本で排気し，穵の後に抵抗加熱したタングステンボート から $\mathrm{Au}(99.99 \%)$ を $0.1 \mathrm{~nm} / \mathrm{s}$ の速度で蒸着した. 薄膜の厚さ は皮晶振動子を用いた膜厚計で読み取りながら $150 \mathrm{~nm}$ だけ唯 積させた。作製した薄膜の(111)方位配向はエレクトロンチャ ンネリングパターン(ECP)解析により確認した。AFM 観察直

† 大阪大学大学院生
前にこの薄膜を水素炎で数分間焼鈍して超高純度窒素ガス (99.9995\%)により十分脱気した純水中で急冷を行った。

AFMは, Nanoscope II (Digital Instruments Inc.) であり， ポテンショスタットを組合せた ECAFMを使用した。探針は $\mathrm{Si}_{3} \mathrm{~N}_{4}$ 製である. 水溶液中での観察には透明なガラス製の電気 化学セルを使用した。観察の詳細は以前 ${ }^{(2)-(5)}$ に報告した場合 と同様なので省略する。電解質溶液は $0.1 \mathrm{MHClO}_{4}$ であり, 純水(伝導度 $0.1 \mu \mathrm{S} / \mathrm{cm}$ 以下) と $\mathrm{HClO}_{4}$ (特級試菜) 加調整し, AFM 観察の直前まで超高純度窒素ガスで十分に脱気した。電 気化学セル内への Clイオンの污染を避行るために対極と参照 極にはAuワイヤー(99.99\%)を使用しており，本研究での作 用電極の電位はこの $\mathrm{Au}$ 参照極に対して報告する。

\section{III. 結果および考察}

真空蒸着によって得られた $\mathrm{Au}(111)$ 薄膜を大気中でAFM 観察した結果を Fig. 1 に示す.（a）に示すように面心立方結晶 の(111)面の 3 回対称性を反映して三角錐台状に成長している ことがわかる。

いくつかのマクロステップが観察されるが，一つ一つの三角 錐台上は原子レベルで平坦であり，(b)k示すような原子分解 能を持つAFM 像が得られる.フーリェ变換像からも3回対 称性が鮮明である. 明るいスポット間の間隔は約 $0.29 \mathrm{~nm}$ で あり, Au の(111)面の原子間距離である $0.288 \mathrm{~nm}$ とよく一致 する. したがって, この表面構造は, 再構成のない $\mathrm{Au}(111)-$ (1×1) 構造と解釈できる。 $0.1 \mathrm{MHClO}_{4}$ 中での $\mathrm{Au}(111)$ 薄膜 で得られた代表的なサイクリックボルタモグラムを Fig. 2 に 示す.これまで報告されているもの ${ }^{(9)}$ と細部は若干異なるが これは，用いた $\mathrm{Au}$ 薄膜が完全な単結晶でなく ECP 解析によ って180度面内回転した双晶が認められたことに起因すると考 えられる.アノード側に見られるメインピーク 1 とピーク 2 は，それぞれ $\mathrm{AuOH}$ と $\mathrm{AuO}$ の生成に対応し，ピーク 3 でそ れらは再び還元される。AFMによるその場観察は，0Vとピ 一ク 1 怙よびピーク 2 Kおいては電位を数10秒間保持して行 った結果を，ピーク 3 では $25 \mathrm{mV} / \mathrm{s} て ゙$ 電位走查をしながら行 った結果を示す。まず，少し大きなエりアでのAFM 観察結果 をFig. 3 に示吉. $0 \mathrm{~V}$ は化学反応のない電気二重層領域住対 応しており，Fig. 3(a)に示すように原子レベルで平滑なテラ 大と数原子層の高さを持つステップがら構成される清浄表面が 

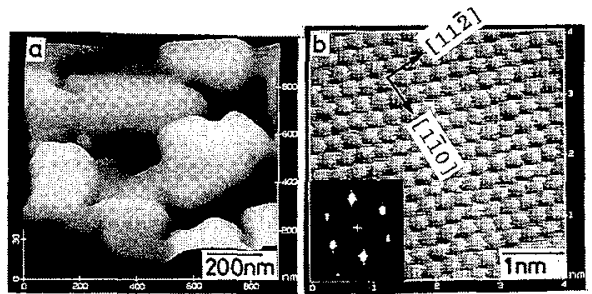

Fig. 1 Large area perspective AFM image (a) and high resolution top-view AFM image (b) of $150 \mathrm{~nm}$-thick $\mathrm{Au}$ (111) film on mica deposited at $600 \mathrm{~K}$. Inset: the corresponding two-dimensional Fourier analysis exhibits the threefold symmetry with spacings of $0.29 \mathrm{~nm}$.

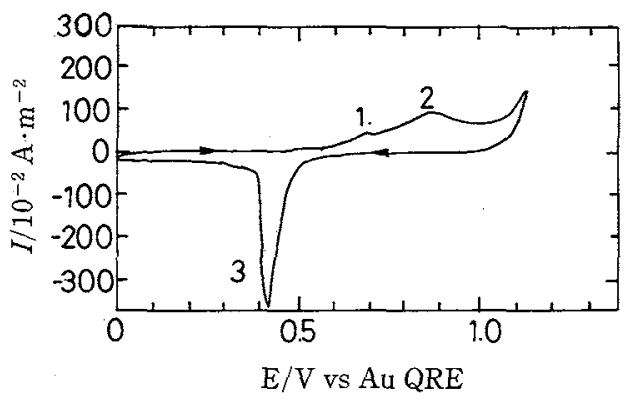

Fig. 2 Typical cyclic voltammogram of $\mathrm{Au}$ (111) film on mica in $0.1 \mathrm{M} \mathrm{HClO}_{4}$ within AFM cell. The scan rate of the electrode potential was $25 \mathrm{mV} / \mathrm{s}$.
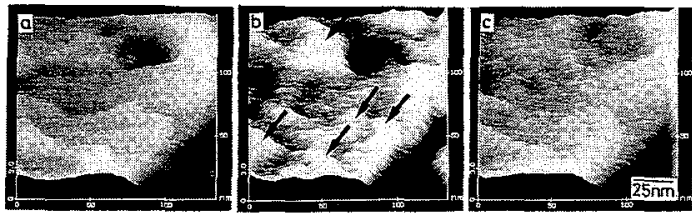

Fig. 3 Large area in-situ AFM images of electrochemical oxidation and reduction of $\mathrm{Au}(111)$ film obtained at $0 \mathrm{~V}$ (a), the anodic peak 1 in fig. 2 (b), the anodic peak 2 in fig. 2 (c).

観察される.アノード側に分極を行い，ピーク1に到達した ところでテラスだけでなく Fig. 3(b)の矢印のように，ステッ プの付近に優先的に大きな起伏が生じて，スパイク状の構造が 観察される。この構造はさらにアノード側のピーク 2 で Fig. 3(c) に示すよらに少し平坦化する，続いて電位を反転させる と，ピーク 3 の付近で酸化物層が還元され再びFig. 3(a) と同 様の清浄な表面が露出された。次に, Fig. 4 亿原子レベルで のAFM 観察結果を示す. 0Vに秃いて, Fig. 4(a)《示すよう に 3 回対称性の鮮明な $0.29 \mathrm{~nm}$ 間隔の $\mathrm{Au}(111)-(1 \times 1)$ 表面構 造が観察される。 $0.1 \mathrm{MHClO}_{4}$ 中では大気中よりるより鮮明に 観察された。この構造は，酸化の始まるピーク1までそのま ま観察されるが，ピーク1に执いて凹凸がかなり大きくなり， 規則的な構造は見られなくなる。次のピーク 2 では Fig. 4(c) のように少し平坦化がするが，やはり規則的な周期構造は認め られない。このような構造が，Fig. 4(d)に示すようにピーク 3 の付近で再び $0.29 \mathrm{~nm}$ 間隔の清浄表面へと変化するのが観察 される.

このような電位を变化させた場合の $\mathrm{HClO}_{4}$ 溶液中に和ける 一連の $\mathrm{Au}(111)$ の表面構造の变化は以前の板谷ら ${ }^{(5)}$ の結果と
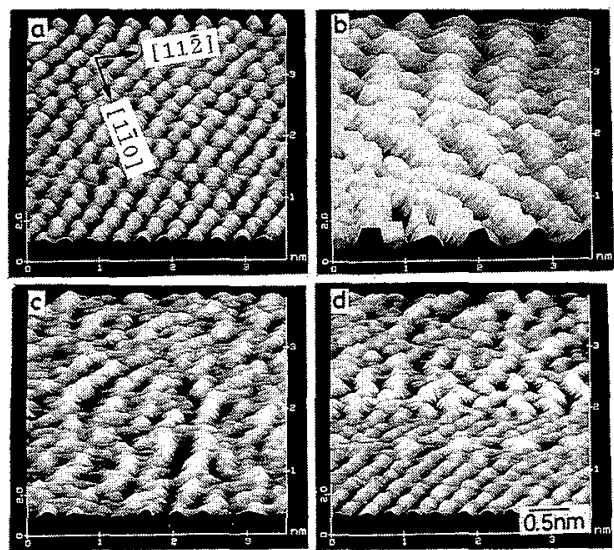

Fig. 4 Atomic-scale in-situ AFM images of electrochemical oxidation and reduction of Au(111) film obtained at 0 $\mathrm{V}$ (a), the anodic peak 1 in fig. 2 (b), the anodic peak 2 in fig. 2 (c), the oxide-stripping peak 3 in fig. 2 (d).

一致している、Angerstein-Kozlowska $ら^{(9)}$ は $\mathrm{HClO}_{4}$ 水溶液中 での $\mathrm{Au}$ の酸化の初期に括いて $\mathrm{Au}$ と吸着した $\mathrm{OH}$ のサイトが 逆転して再構成が生ずることを報告しているが，ピーク1の 電位で得られた大きなェッアと原子レベルの AFM 像のスパイ ク状の構造はこれ対応しているものと解釉される。本研究で は, 新たにピーク 1 の $\mathrm{AuH}$ の生成においてステップの付近 で優先的に起伏が激しくなることと電気化学的酸化化う $\mathrm{Au}(111)$ 表面のモルフォロジーの変化の詳細が明らかとなっ た. また，電気二重層領域では Auの清浄表面が原子レベル観 察されることから，AFM 電解質溶液中に打梳金属表面の 観察として有力で梁り，今後貴金属以外の金属表面への適用が 期待される。

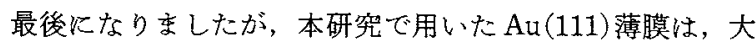
阪大学理学部工作センターで作成したことを付記し, 御尽力を 賜った西脇 醇助教授ならびに西山雅祥氏に謝意を表します。 また ECP 解析にあたり卸尽力賜った大阪大学工学部柴柳敏哉 博士に謝意を表しをず。

\section{文献}

(1) G. Binnig, H. Rohrer, Ch. Gerber and E. Weibel: Phys. Rev. Lett., 50 (1983), 120.

(2) G. Binnig, C. F. Quate and Ch. Gerber: Phys. Rev. Lett., $\mathbf{5 6}(1986), 930$.

（3）例えば N. Ikemiya, S. Hara, K. Ogino and T. Nakajima: Surf. Sci., 274(1992), L524.

(4) T. Hachiya, H. Honbo and K. Itaya: J. Electroanal. Chem., 315(1991), 275.

(5) H. Honbo, S. Sugawara and K. Itaya: Anal. Chem., $62(1990), 2424$

(6) D. J. Trevor, C. E. D. Chidsey and D. N. Loiacono: Phys. Rev. Lett., 62(1989), 929.

(7) L. Vazquez, A. Bartolome, A. M. Baro, C. Alonso, R. C. Salvarezza and A. J. Arvia: Surf. Sci., 215 (1989), 171.

(8) S. Manne, J. Massie, V. B. Elings, P. K. Hansma and A. A. Gewirth: J. Vac. Sci. Technol., B9(1991), 950.

(9) H. Angerstein-Kozlowska, B. E. Conway, A. Hamelin and L. Stoicoviciu: Electrochimica Acta., 31(1986), 1051.

（1993年 6 月 14 日受付） 